\title{
Development of early-stage embryos of the Japanese field vole, Microtus montebelli, in vivo and in vitro
}

\author{
T. Wakayama ${ }^{1}$, Y. Matsubara ${ }^{2}$, K. Imamura ${ }^{2}$, M. Kurohmaru ${ }^{1}$, \\ Y. Hayashi ${ }^{1}$ and K. Fukuta ${ }^{2}$ \\ ${ }^{1}$ Department of Veterinary Anatomy, Faculty of Agriculture, The University of Tokyo, Bunkyo-ku, \\ Tokyo 113, Japan; and ${ }^{2}$ National Institute of Animal Health, Tsukuba, Ibaraki 305, Japan
}

\begin{abstract}
Although ovulation could be easily induced in the Japanese field vole by administering pregnant mares' serum gonadotrophin and hCG, the number of embryos obtained varied from 1 to 47 (mean, 9.6). One-cell embryos were small $(57.8-63.3 \mu \mathrm{m}$ in diameter; mean, $61.0 \mu \mathrm{m}$ ) compared with those in other mammals. Development of the preimplantation vole embryos in vivo was similar to that of mouse embryos. The first cleavage occurred between 24 and $26 \mathrm{~h}$ after mating. The second cleavage was between 46 and $52 \mathrm{~h}$ after mating, and subsequent cleavages occurred at about $12 \mathrm{~h}$ intervals. Blastocysts were clearly observed in the uterus 4 days after mating. Vole embryos could be cultured in vitro from the late two-cell to the blastocyst stage in M16 medium. However, development of one-cell and early two-cell embryos in vitro was limited, and few cleaved beyond the four-cell stage. Eliminating sodium pyruvate from M16 medium significantly improved the development of early two-cell embryos into blastocysts $(P<0.05)$. The Japanese field vole may be a useful experimental animal for reproductive biology, comparable with the mouse.
\end{abstract}

\section{Introduction}

The Japanese field vole, Microtus montebelli, is a herbivorous rodent known to be a potential animal model for herbivorous domestic animals (Kudo and Oki, 1984; Imai and Ogimoto, 1988; Obara and Goto, 1988). Although the field vole has been reported to have a digestive tract characteristic of this group of animals, little is known about its reproduction. Goto and Hashizume (1978) and Goto et al. (1977) reported that the Japanese field vole exhibits a copulatory ovulation and that its vaginal smear does not indicate a regular oestrous pattern. In a previous study (Wakayama et al., 1993), we demonstrated that vole spermatozoa can penetrate the zona pellucida of mice and hamster eggs. Knowledge of embryonic development in vivo plus the ability to support cleavage in vitro permits the study of the physiology of early embryos in a defined environment, and also facilitates the determination of storage and transport requirements for embryo transfer and manipulation. In the present study, we examined the preimplantation development of early-stage Japanese field vole embryos in vivo and in vitro.

\section{Materials and Methods}

\section{Animals}

The Japanese field voles used in this study had been maintained by outbred mating at the National Institute of Animal Health, Tsukuba for more than 15 years. The voles were housed at $25^{\circ} \mathrm{C}$ under a controlled photoperiod of $14 \mathrm{~h}$ light: $10 \mathrm{~h}$ dark. The animals were fed commercial mouse diets (CMF, Oriental East Co., Ltd, Tokyo), a herbivorous diet (ZF, Oriental East Co., Ltd, Tokyo), and cubed hay. Food and water were given ad libitum.

\section{Induction of ovulation and recovery of embryos}

Sexually mature female voles $(n=74)$ were injected i.p. with 75 iu pregnant mares' serum gonadotrophin (PMSG) (Adachi et al., 1993) at $13.00 \mathrm{~h}$, followed by $30 \mathrm{iu}$ hCG at 06.00 or $13.00 \mathrm{~h} 2$ days later. Each animal was placed with a fertile male for $\mathrm{Ih}$, during which mating occurred. Mated females were then separated from the males, and embryos were recovered by flushing the reproductive tracts $12-92 \mathrm{~h}$ after mating. If unfertilized or one-cell eggs were found to contain cumulus cells, they were treated with $0.1 \%(\mathrm{w} / \mathrm{v})$ hyaluronidase to remove the cumulus cells. M16 medium (Whittingham, 1971) was used to flush the tracts and wash the embryos. The diameters of fertilized one-cell embryos and unfertilized oocytes (i.e. vitellus alone) were measured within $22 \mathrm{~h}$ after mating using the calibrated eyepiece micrometer of a microscope.

\section{Culture conditions}

About 20 embryos were cultured in $3 \mathrm{ml}$ fresh M16 medium in plastic Petri dishes (diameter $35 \mathrm{~mm}$ ) at $37^{\circ} \mathrm{C}$, under $5 \% \mathrm{CO}_{2}$ in air. Their developmental stage was examined every $24 \mathrm{~h}$. Some early two-cell embryos (recovered within $26 \mathrm{~h}$ after 

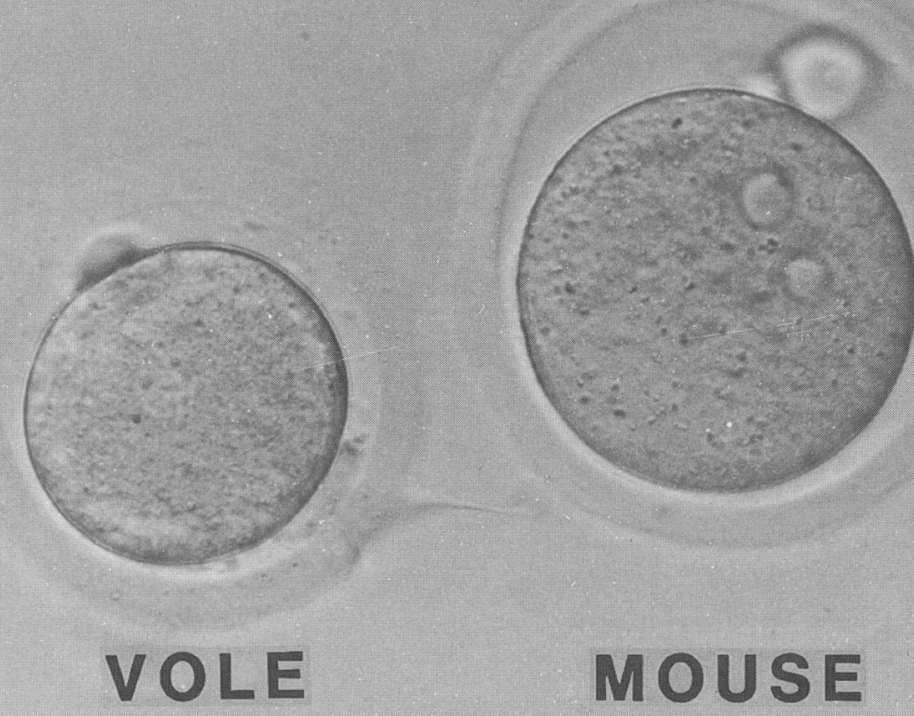

MOUSE

Fig. 1. Comparative sizes of one-cell embryos in Japanese field voles and mice. Although the vole embryos are smaller (61.0 $\mu \mathrm{m}$ in diameter) than mouse embryos, the zona pellucida is thicker than in mice. Scale bar represents $20 \mu \mathrm{m}$.

mating) were cultured for the first $24 \mathrm{~h}$ in M16 medium supplemented with $100 \mu \mathrm{mol}$ EDTA ${ }^{-1}$ (MI6-EDTA) or in M16 without sodium pyruvate (M16-PF). The developmental rates of embryos in the different media were compared statistically using the chi-squared test.

\section{Results}

\section{Ovulation}

Ovulation occurred in voles after administration of PMSG and hCG, but the number of ovulated eggs was lower than that in the mouse and hamster. Of 74 females given both PMSG and hCG, $62(83.8 \%)$ mated, and no embryos were found in eight mated females. A total of 519 embryos was obtained from the remaining 54 females (a mean of $9.6 \pm 5.3$ embryos per female). The number of embryos in each female varied from 1 to 47 . The diameter of one-cell embryos (vitellus alone) ranged from 57.8 to $63.3 \mu \mathrm{m}$ (a mean of $61.0 \pm 1.3 \mu \mathrm{m} ; n=10$; number of embryos $=58$; Fig. 1).

\section{Development in vivo}

Eggs were ovulated within $12 \mathrm{~h}$ and remained at the one-cell stage until $22 \mathrm{~h}$ after mating (Table 1). The first cleavage occurred between 24 and $26 \mathrm{~h}$. Four-cell embryos were first counted after $46 \mathrm{~h}$ and constituted $46.7 \%$ of all embryos obtained between 46 and $52 \mathrm{~h}$. These results indicate that the second cleavage takes place between 46 and $52 \mathrm{~h}$ after mating. Thereafter, cleavages occurred about every $12 \mathrm{~h}$. Blastocysts were found in the uterus after $94 \mathrm{~h}$.

\section{Development in vitro}

The development of one-cell and early two-cell embryos (collected within $26 \mathrm{~h}$ after mating) in vitro was limited and few cleaved beyond the four-cell stage (only 14\% developed to blastocysts) (Table 2). However, the late two-cell embryos collected $45 \mathrm{~h}$ after mating developed readily to blastocysts $(64 \%)$ in M16 medium. A higher proportion of four-cell and eight-cell embryos also developed to blastocysts $(89 \%$ and $91 \%$, respectively). Although many blastocysts expanded, none hatched in M16 medium.

In an attempt to overcome the block to development at the early two-cell stage, early two-cell embryos were cultured in M16 supplemented with EDTA (M16-EDTA) or in pyruvatefree M16 (M16-PF). Only 8-18\% of the embryos cultured in M16 and M16 plus EDTA developed to blastocysts (Table 3). In M16-PF, development of the embryos to blastocysts was significantly increased to $42 \%$. 
Table 1. Development of Japanese field vole embryos in vivo

\begin{tabular}{|c|c|c|c|c|c|c|c|c|c|}
\hline \multirow{2}{*}{$\begin{array}{l}\text { Time }(\mathrm{h}) \\
\text { after mating }\end{array}$} & \multirow{2}{*}{$\begin{array}{c}\text { Number of } \\
\text { voles }\end{array}$} & \multirow{2}{*}{$\begin{array}{c}\text { Number of } \\
\text { eggs }\end{array}$} & \multicolumn{7}{|c|}{ Developmental stage } \\
\hline & & & One-cell & Two-cell & Four-cell & Eight-cell & Morula & Blastocyst & Abnormal \\
\hline 12 & 2 & 35 & 35 & & & & & & 0 \\
\hline $21-22$ & 3 & 26 & 25 & 1 & & & & & 0 \\
\hline $24-26$ & 5 & 98 & 24 & 64 & & & & & 10 \\
\hline $45-46$ & 4 & 19 & & 13 & 2 & & & & 4 \\
\hline $48-49$ & 4 & 52 & & 21 & 25 & & & & 6 \\
\hline $50-52$ & 3 & 20 & & 7 & 9 & & & & 4 \\
\hline $60-62$ & 5 & 33 & & & 4 & 16 & & & 13 \\
\hline $72-73$ & 2 & 25 & & & & 10 & 15 & & 0 \\
\hline 94 & 1 & 9 & & & & & 5 & 4 & 0 \\
\hline
\end{tabular}

Table 2. Development of Japanese field vole embryos in vitro

\begin{tabular}{|c|c|c|c|c|c|c|}
\hline \multirow{2}{*}{$\begin{array}{l}\text { Collection time } \\
\text { after mating }(\mathrm{h})\end{array}$} & \multirow{2}{*}{$\begin{array}{l}\text { Stage of } \\
\text { embryos }\end{array}$} & \multirow{2}{*}{$\begin{array}{l}\text { Number of } \\
\text { embryos }\end{array}$} & \multicolumn{4}{|c|}{ Number of developing embryos (\%) } \\
\hline & & & $\geqslant$ Two-cell & $\geqslant$ Four-cell & $\geqslant$ Eight-cell & $\geqslant$ Blastocyst \\
\hline $12-22$ & One-cell & 44 & $36(82)$ & $5(11)$ & $1(2)$ & 1 (2) \\
\hline $24-26$ & Two-cell (early) & 44 & & $17(38)$ & $7(16)$ & $6(14)$ \\
\hline $45-52$ & Two-cell (late) & 28 & & $24(82)$ & $19(64)$ & $19(64)$ \\
\hline $45-62$ & Four-cell & 35 & & & $34(97)$ & $31(89)$ \\
\hline $60-73$ & Eight-cell & 22 & & & & $20(91)$ \\
\hline
\end{tabular}

Table 3. Culture of early two-cell embryos of the Japanese field vole in vitro

\begin{tabular}{|c|c|c|c|c|c|}
\hline \multirow[b]{2}{*}{ Medium } & \multirow{2}{*}{$\begin{array}{c}\text { Number of } \\
\text { voles }\end{array}$} & \multirow{2}{*}{$\begin{array}{c}\text { Number of } \\
\text { embryos }\end{array}$} & \multicolumn{3}{|c|}{ Number of developing embryos (\%) } \\
\hline & & & $\geqslant$ Four-cell & $\geqslant$ Eight-cell & $\geqslant$ Blastocyst \\
\hline M16 & 4 & 28 & $17(61)^{b}$ & $5(18)^{\mathrm{a}}$ & $5(18)^{a}$ \\
\hline M16-EDTA & 8 & 66 & $19(29)^{\mathrm{a}}$ & $5(8)^{\mathrm{a}}$ & $5(8)^{a}$ \\
\hline M16-PF & 8 & 65 & $47(72)^{\mathrm{b}}$ & $28(43)^{\mathrm{b}}$ & $27(42)^{b}$ \\
\hline
\end{tabular}

a.b Values with different superscripts are significantly different $(P<0.05)$.

Data from four replicates were pooled.

PF: pyruvate-free.

\section{Discussion}

Ovulation may be induced in the Japanese field vole by administration of PMSG and hCG. Adachi et al. (1993) reported that the mean number of eggs obtained was highest (9.1 eggs, including abnormal eggs) when 30 iu hCG was injected $48 \mathrm{~h}$ after 75 iu PMSG. In the present study, the interval between the injections of the two hormones was $42 \mathrm{~h}$ yielding an average of 24.0 eggs per animal. The vole colony used in this study was genetically diversified (outbred), which might have caused a greater variability in the number of ovulations (1-47).

Blastocysts are found in vivo 4 days after hCG injection in mice, after 3.5 days in hamsters, and after 5 days in rats. Mystkowska (1975a) reported that the preimplantation devel- opment of bank voles, Clethrionomys glareolus, resembles that of mice. The development of Japanese field vole embryos is similar to that of mice and bank voles.

Vole embryos can be cultured from the late two-cell to the blastocyst stage in M16, a medium devised for mouse embryos. Although the development of early two-cell embryos was limited in M16 or M16-EDTA, these embryos formed blastocysts at a rate significantly greater in M16-PF than in M16 or M16-EDTA $(P<0.01)$.

It is well known that EDTA can assist in overcoming the two-cell block in mouse embryos (Abramczuk et al., 1977; Hoshi and Toyoda, 1985) and that the eight-cell block in hamsters may be overcome by chelating agents (Kameyama and Ishijima, 1991). However, supplementing with EDTA does 
not overcome the two-cell block in vole embryos. Although sodium pyruvate is necessary for culture of mouse two-cell embryos (Brinster, 1965) and is consumed preferentially as an energy substrate during the early developmental stages of mouse (Leese and Barton, 1984; Gardner and Leese, 1986), rat (Brison and Leese, 1991) and human embryos (Hardy et al., 1989), it is inhibitory to the development of hamster and pig embryos (Davis and Day, 1978; Davis, 1985; McKiernan et al., 1991). These data suggest that there is species specificity in the type of energy source required by early preimplantation stage embryos.

The mean diameter of one-cell Japanese field vole embryos in this study was $61.0 \mu \mathrm{m}$. Austin (1957) reported that the eggs of the field vole, Microtus agrestis, were the smallest of all mammals that had been studied at the time, and Mystkowska (1975b) found that bank vole embryos were smaller and darker than mouse embryos. Niimura et al. (1987) found that Japanese field vole embryos possessed fewer lipid droplets in the cytoplasm than did mouse embryos. The Japanese field vole embryos were smaller than mouse embryos (which are $80 \mu \mathrm{m}$ in diameter, Austin, 1961), although the features of both were similar. It is therefore possible to distinguish vole and mouse embryos by size.

The present study indicates that embryos of Japanese field voles can be cultured readily in medium used for mouse embryos and that development from one-cell embryos to the blastocyst in vivo is similar to that in mice rather than in rats and hamsters. The Japanese field vole may be a useful experimental animal for reproductive biology in addition to the mouse.

\section{References}

Abramczuk J, Solter D and Koprowski A (1977) The beneficial effect of EDTA on the development of mouse one-cell embryos in chemically defined medium Developmental Biology 61 378-383

Adachi M, Tanaka R, Yoshida T and Tsushima M (1993) Studies on induced superovulation in mature nulliparous Japanese voles (Microtus montebelli) following gonadotrophin administration Journal of Reproduction and Development $39 \mathrm{j} 7-\mathrm{j} 10$

Austin CR (1957) Fertilization, early cleavage and associated phenomena in the field vole (Microtus agrestis) Journal of Anatomy 91 1-11

Austin CR (1961) General biology of eggs. In The Mammalian Eg8 pp 1-15 Ed. CR Austin. Blackwell Scientific Publications, Oxford

Brinster RL (1965) Studies on the development of mouse embryos in vitro. II. The effect of energy source Joumal of Experimental Zoology 158 59-68
Brison DR and Leese HJ (1991) Energy metabolism in late preimplantation rat embryos Journal of Reproduction and Fertility 93 245-251

Davis DL (1985) Culture and storage of pig embryos Journal of Reproduction and Fertility Supplement 33 115-124

Davis DL and Day BN (1978) Cleavage and blastocyst formation by pig eggs in vitro Journal of Animal Science 46 1043-1053

Gardner DK and Leese HJ (1986) Non-invasive measurement and nutrient uptake by single cultured preincubation mouse embryos Human Reproduction $125-27$

Goto N and Hashizume R (1978) Pattern of ovulation in Microtus montebelli Joumal of the Mammalogical Society of Japan 7 181-189

Goto N, Hashizume R and Sai I (1977) Litter size and vaginal smear in Microtus montebelli Journal of the Mammalogical Society of Japan 7 75-85

Hardy K, Hooper MAK, Handyside AJ, Winston RML and Leese HJ (1989) Non-invasive measurement of glucose and pyruvate by individual human oocytes and preimplantation embryos Human Reproduction 4 188-191

Hoshi $M$ and Toyoda $Y$ (1985) Effect of EDTA on the preimplantation development of mouse embryos fertilized in vitro Japanese Journal of Zootechnical Science 56 931-937

Imai $S$ and Ogimoto $K$ (1988) Flagellate protozoa in the digestive tract of the Japanese field vole, Microtus montebelli Japanese Joumal of Zootechnical Science 59 351-356

Kameyama $Y$ and Ishijima $Y$ (1991) In vitro culture of Chinese hamster ova journal of Mammalian Ova Research 8 15-20

Kudo H and Oki Y (1984) Microtus species as a new herbivorous laboratory animal: reproduction; bacterial flora and fermentation in the digestive tracts; and nutritional physiology Veterinary Research Communications 8 77-91

Leese HJ and Barton AM (1984) Pyruvate and glucose uptake by mouse ova and preimplantation embryo Journal of Reproduction and Fertility 72 9-13

McKiernan SH, Bavister BD and Tasca RJ (1991) Energy substrate requirements for in vitro development of hamster 1- and 2-cell embryos to the blastocyst stage Human Reproduction 6 64-75

Mystkowska ET (1975a) Preimplantation development in vivo and in vitro in bank voles, Clethrionomys glareolus, treated with PMSG and hCG Journal of Reproduction and Fertility 42 287-292

Mystkowska ET (1975b) Development of mouse-bank vole interspecific chimaeric embryos Journal of Embryology and Experimental Morphology 33 $731-744$

Niimura S, Imamura K, Goto N and Isida K (1987) Histochemical observations of proteins, polysaccharides and lipids in the oocytes and embryos of Japanese field voles (Microtus montebelli) during folliculogenesis and early development Japanese Journal of Animal Reproduction 33 6-10

Obara $\mathrm{Y}$ and Goto N (1988) Utilization of endogenous nitrogen in the Japanese field vole (Microtus montebelli) Japanese Joumal of Zootechnical Science $\mathbf{5 9}$ 733-739

Wakayama T, Maruyama Y, Imamura K and Fukuta K (1993) Penetration of the zona pellucida of eggs of different species by spermatozoa of the Japanese field vole, Microtus montebelli Journal of Reproduction and Development 39 319-323

Whittingham DG (1971) Culture of mouse ova Journal of Reproduction and Fertility Supplement 14 7-21 